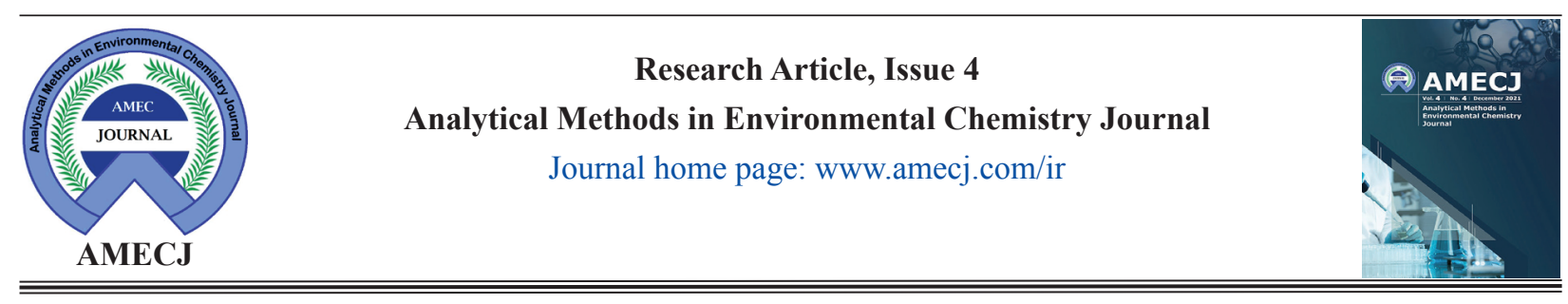

\title{
Synthesis and identification of meta-(4-bromobenzyloxy) benzaldehyde thiosemicarbazone (MBBOTSC) as novel ligand for cadmium extraction by ultrasound assisted- dispersive-ionic liquid-liquid micro extraction method
}

Abdolreza Hassanzadeha, Bagher Amirheidari ${ }^{\mathbf{b}}$, Ahmad Salarifarc, Ali Asadipour and Yaghoub Pourshojaei a,*
a Department of Medicinal Chemistry, Faculty of Pharmacy, Kerman University of Medical Sciences, Kerman, Iran.-
${ }^{b}$ Department of Pharmaceutical Biotechnology, Faculty of Pharmacy, Kerman University of Medical Sciences, Kerman, Iran
${ }^{c}$ Environmental Engineering, Faculty of Natural Resources, Islamic Azad University, Bandar Abbas Branch, Iran

A R T I C L E I N F O :

Received 13 Aug 2021

Revised form 20 Oct 2021

Accepted 19 Nov 2021

Available online 30 Dec 2021

Keywords:

Cadmium,

Meta-(4-bromobenzyloxy)

benzaldehyde thiosemicarbazone,

Ligand,

Synthesis,

Metal extraction,

Ultrasound assisted-dispersive-ionic liquid-liquid microextraction

\begin{abstract}
A B S T R A C T
In this research, meta-(4-bromobenzyloxy) benzaldehyde thiosemicarbazone (MBBOTSC) as a novel ligand was synthesized from the reaction between meta-(4-bromobenzyloxy) benzaldehyde and thiosemicarbazide under basic condition in water and ethanol as solvents. Ligand has the ability to chelate ions and therefore, it was used to form a complex and extract ions. So, the cadmium ions in water and wastewater samples were separated based on MBBOTSC by ultrasound assisted-dispersive-ionic liquid-liquid microextractionmethod (USA-D-ILLME) before determination by AT-F-AAS.The MBBOTSC ligand was added to the mixture of the ionic liquid/acetone(IL/AC, $[\mathrm{OMIM}]\left[\mathrm{PF}_{6}\right]$ ) and then injected by syringe to $50 \mathrm{~mL}$ of water samples at $\mathrm{pH}$ 6-7.The sample was put into the ultrasonic accessory for 5 minutes, after complexation (Ligand-Cd; RS...Cd....RS), the water sample was centrifuged for $3 \mathrm{~min}$ for phase separation.Due to complexation and back-extraction of $\mathrm{Cd}$ in liquid phase,the amount of $\mathrm{Cd}$ ions in the water samples was determined by AT-F-AAS after dilution eluent $\left(0.5 \mathrm{M}, \mathrm{HNO}_{3}\right)$ with DW up to $1 \mathrm{~mL}$.In optimized conditions, the Linear ranges and LOD for $50 \mathrm{~mL}$ of water samples were obtained 1-36 $\mu \mathrm{g} \mathrm{L}^{-1}$ and $0.3 \mu \mathrm{g} \mathrm{L}^{-1}$, respectively (Mean $\mathrm{RSD}=1.26 \%$ ). The validation results were successfully achieved by spiking real samples and using electrothermalatomic absorption spectrometry (ET-AAS).
\end{abstract}

\section{Introduction}

Thiosemicarbazones (TSCs) are an important class of organic compounds containing $\mathrm{N}$ and $\mathrm{S}$ elements that have various uses and properties [1]. These compounds as Schiff base ligands have been widely used to form complexes and to separate metals [2]. Furthermore, due to the presence

*Corresponding Author: YaghoubPourshojaei

Email: pourshojaei@yahoo.com

https://doi.org/10.24200/amecj.v3.i04.161 of electron pairs on sulfur and nitrogen, these compounds are used over a large area (Fig. 1). TSCs form a prominent class of pharmaceuticals and biologically active compounds by virtue of their antimicrobial, antiviral, anti-bovine viral diarrhea, antiproliferative and antifungal activities [3-7]. Also, the formation of metal complexes plays a very important role in the treatment of cancer, especially since there are reports of the destructive role of reactive oxygen species in increasing the antiproliferative activity of chelators against 
tumour cells [8]. Synthesis of TSC is performed in different ways: a) it is a two-step pathway in which hydrazine reacts with isothiocyanate and the product with aldehyde or ketone, which leads to TSCs [9], b) it is the opposite of pathway a, ie hydrazine first reacts with aldehydes or ketones and then the resulting compound reacts with isothiocyanate [10], c) it is a 4-step process, in which hydrazine first reacts with carbon disulfide and the resulting intermediate reacts with methyl iodide to form methylhydrazine thiocarbamate, eventually nucleophilic substitution with amines and a condensation reaction with an aldehyde or ketone produces TSC [11]. In continuation of our research on the synthesis of various compounds [12-15] and recent report introducing penicillamine as a metal chelator [16], herein, MBBOTSC as ligand containing sulfur and nitrogen has proposed as cadmium chelator.

The toxicity of cadmium (Cd) in water is very important because of the long half-life in the human body. The high toxicity of cadmium caused to damage human organs such as kidneys, liver, lungs and cancer [21,22]. Cadmium is easily transferred from water to plants/humans and has also contamination in the environment [23]. The environmental protection agency (EPA) and Agency for Toxic Substances and Disease Registry reported that cadmium values in the waters are usually less than $5 \mu \mathrm{g} \mathrm{L}^{-1}[24]$. For healthy people, the mean cadmium concentration in human serum samples is less than $0.2 \mu \mathrm{g} \mathrm{L}^{-1}[25]$. So, the determination of cadmium in water samples is an important concern for controlling toxicity [26,27]. The sensitive techniques such as the electrothermal atomic absorption spectrometry (ET-AAS) [28], the atom trap assist to flame atomic absorption spectrometry and flame atomic absorption spectrometry (AT-FAAS, F-AAS) [29], inductively coupled plasmaatomic emission spectrometry (ICP-AES) using thiosemicarbazide derivative on alumina [30], and inductively coupled plasma-mass spectrometry (ICP-MS) [31], was used for the determination of cadmium in water and wastewater samples. However, as a low concentration of cadmium and high interferences in wastewater samples, sample preparation before analysis is required. Solid-phase extraction (SPE) and liquid-liquid micro extraction (LLME) are preferred to other techniques for ultratrace cadmium determination and separation in water samples [ 32,33].

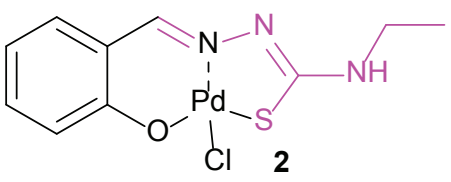

Pd thiosemicarbazone Complex, as Catalysts for Cross-Coupling Reactions [18]

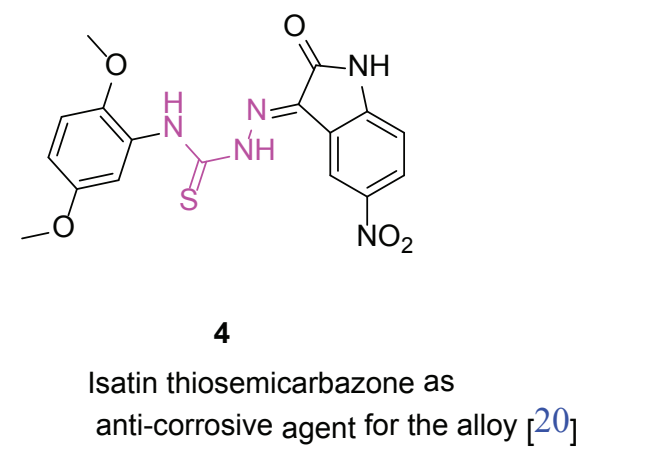

Fig. 1. Several TSC drivatives with different application 
Herein a TSC as ligand containing sulfur and nitrogen was synthesized in two steps; a) synthesis of a primary aldehyde; meta-(4-bromobenzyloxy) benzaldehyde, b) synthesis of final ligand meta-(4-bromobenzyloxy) benzaldehyde thiosemicarbazone (Scheme 1). Then the structure of the final ligand was identified by spectroscopic methods such as NNR and IR as well as TLC and melting point.

In this study, the ligand structure was identified by spectroscopic methods such as ${ }^{1} \mathrm{HNMR}$, ${ }^{13} \mathrm{CNMR}$, and FTIR as well as melting point. Thin layer chromatography (TLC) was used to check the progress of the reaction (ethyl acetate and n-hexane were used as the mobile phase). Finally, the mixture of MBBOTSC ligand, IL and acetone was used for cadmium extraction based on the USA-D-ILLME procedure at $\mathrm{pH}$ 6-7 before determined by the AT-F-AAS. The results were validated by spiking of water samples and compared to the ET-AAS.

\section{Experimental}

\subsection{Instrumental Analysis}

The atom trap flame atomic absorption spectrometry (AT-F-AAS) was used for cadmium determination in water and wastewater samples. The signal absorption improved by the atom trap accessory was added to the burner AAS which was caused to increase the sensitivity of absorption for cobalt analysis. The limits of detection (LOD) for AT-FAAS and FAAS were achieved 0.05 and 0.2 $\mathrm{mg} \mathrm{L}^{-1}$, respectively. The information of cobalt was entered to software Avanta (wavelength of 228.8 $\mathrm{nm}, 3.0 \mathrm{~mA}$ and silt of $0.5 \mathrm{~nm}$ ). The auto-sampler was used for all samples. The linear range for ATFAAS was $0.05-1.8 \mathrm{mg} \mathrm{L}^{-1}$ for cobalt analysis. The validation of results was checked by electrothermal atomic absorption spectrophotometer (GBC, Aus) in water samples $\left(0.2-6.0 \mu \mathrm{g} \mathrm{L}^{-1}\right)$. The $\mathrm{pH}$ of the water samples was tuned by the buffer solutions of Merck, Germany before measured by the digital $\mathrm{pH}$ meter (Metrohm, Swiss). The phosphate buffers have adjusted the $\mathrm{pH}$ for 6-7.

\subsection{Reagents and Materials}

All reagents/starting materials and solvents used in this study were purchased from commercial suppliers (Merck AG, Aldrich or Acros Organics). The melting point was measured on an electrothermal IA9100 melting point apparatus fixed at $1{ }^{\circ} \mathrm{C}$ per minute and are uncorrected. The reagents of phosphate buffers (CAS N: 7558-79-4) were prepared from Sigma Aldrich, Germany. The ionic liquid of 1-methyl-3octylimidazolium hexafluorophosphate ([OMIM] [PF 6 , CAS N: 304680-36-2) was prepared from Sigma Aldrich, Germany. The calibration standards containing $1,5,10,20,25,35 \mu \mathrm{g} \mathrm{mL}^{-1} \mathrm{Cd}$ standard solutions were prepared by dissolving $1.0 \mathrm{~g}$ of cadmium nitrate $\left(\mathrm{Cd}\left(\mathrm{NO}_{3}\right)_{2}\right)$ in $1 \mathrm{~L}$ of deionized water solution ( $\mathrm{DW}$ in $2 \% \mathrm{HNO}_{3}$ ). The standard of Cd solutions was daily made by stock solutions (1g L $\left.{ }^{-1}, 1000 \mathrm{~m} \mathrm{~L} \mathrm{~L}^{-1}\right)$ which was diluted by DW up to one litre (Millipore, USA). Other reagents such as $\mathrm{HCl}, \mathrm{HNO}_{3}$ and acetone were purchased from Merck, Germany.

\subsection{Charactrization}

IR spectra were recorded using Nicolet FT-IR Magna 550 spectrographs ( $\mathrm{KBr}$ disks). The NMR spectra were recorded on Bruker 300 spectrometers in DMSO- $d_{6}$ as solvent. ${ }^{1} \mathrm{H}$ NMR data are reported in the following order: Chemical shifts $(\delta)$ in part per million (ppm) downfield from TMS as internal standard; approximate coupling constant values $(J)$ in Hertz (HZ); spin multiplicities (s, singlet; $\mathrm{d}$, doublet; t, triplet. Thin-layer chromatography (TLC) was performed on pre-coated Silica Gel F254 plates in ethyl acetate: n-hexane as the mobile phase, for checking the reactions.

\subsection{Synthesis of meta-(4-bromobenzyloxy) benzaldehyde}

The meta-(4-bromobenzyloxy) benzaldehyde was prepared by reaction of 3-hydroxybenzaldehyde with 4- bromobenzylchloride in the presence of $\mathrm{K}_{2} \mathrm{CO}_{3}$ as catalyst. The physical and chemical properties of it, was compared with literature and its structure was confirmed [34] 


\subsection{Synthesis of MBBOTSC}

In a $50 \mathrm{ml}$ round bottom flask equipped with a magnet, dissolved $0.1 \mathrm{~g}$ of $\mathrm{NaOH}$ in $5 \mathrm{cc}$ of distilled water, at first $1 \mathrm{mmol}(0.291 \mathrm{mg}$ ) of meta-(4-bromobenzyloxy) benzaldehyde and then gradually $1 \mathrm{mmol}(0.091$ g) of thiosemicarbazide was added to the resulting solution. And the mixture was gently stirred for one day. Then $5 \mathrm{cc}$ of ethanol was added and refluxed for one hour. The reaction progress was controlled by TLC EtOAc/n-hexane (1:3) as eluent. The obtained sediments were filtered using filter paper and dried in a vacuum. Then the precipitate was recrystilized in boiling ethanol. At the end, crystalline product was filtrated to obtain crystalline pure product (Scheme 1). The structure, yield, melting point of synthesized compound is given in the Table 1. Also, the FT-IR, ${ }^{1} \mathrm{H}$ NMR and ${ }^{13} \mathrm{C}$ NMR spectra of the synthesized ligand are shown in Figures 3 to 5, respectively.

\subsection{Procedure of metal extraction}

By the USA-D-ILLME procedure, the cadmium was complexed with the MBBOTSC ligand in water and wastewater samples. Also, the Co ions was determined by AT-F--AAS. The MBBOTSC ligand $(0.1 \mathrm{~g})$ added to mixture of [OMIM] $\left[\mathrm{PF}_{6}\right]$ and acetone $(0.2 \mathrm{~g}: 500 \mu \mathrm{L})$ and was injected into $50 \mathrm{~mL}$ of Cd included 1-36 $\mu \mathrm{g} \mathrm{L}-1$. After shaking of samples (5.0 $\mathrm{min})$, the cobalt ions were extracted with sulfur and nitrogen groups of MBBOTSC ligand [R$\mathrm{N}:(\mathrm{S}:) \ldots . . \mathrm{Cd}(\mathrm{II}) \longleftarrow(\mathrm{S}) \mathrm{N}:-\mathrm{R}]$ at $\mathrm{pH}$ 6. After the complexation, the Cd-MBBOTSC was separated with IL $[\mathrm{OMIM}]\left[\mathrm{PF}_{6}\right]$ at the bottom of a PVC conical tube by centrifuging for $3 \mathrm{~min}$ and speed of $4000 \mathrm{rpm}$. The water samples were set aside by auto-sampler $(50 \mathrm{~mL})$ and the $\mathrm{Cd}$ ios in IL phase back-extracted by $0.5 \mathrm{~mL}$ of $\mathrm{HNO}_{3}(0.5 \mathrm{M})$. After diluted acide phase with DW up to $1.0 \mathrm{~mL}$, the $\mathrm{Cd}$ values was determined by AT-FAAS. The procedure was shown in Figure 2. The enrichment factor (EF) based on the slope of calibration curve of $\mathrm{Cd}$ in the proposed procedure (USA-D-ILLME) and standard method was calculated $\left(m_{1} / m_{2}=\operatorname{tg} \alpha, E F=49.64\right)$.<smiles>O=Cc1cccc(O)c1</smiles>

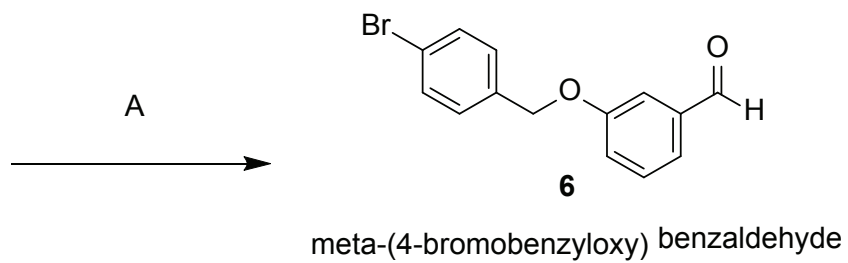<smiles>NC(=S)NN/C=N\c1cccc(OCc2ccc(Br)cc2)c1</smiles>

meta-(4-bromobenzyloxy) benzaldehyde thiosemicarbazone

Scheme 1. A) Synthesis of meta-(4-bromobenzyloxy) benzaldehyde 6 B) meta-(4-bromobenzyloxy) benzaldehyde thiosemicarbazone 8, Reagents and conditions: (a) $\mathrm{K}_{2} \mathrm{CO}_{3}$, DMF, $100{ }^{\circ} \mathrm{C}$; (b) $\mathrm{NaOH}, \mathrm{H}_{2} \mathrm{O}$, EtOH, reflux.

Table 1. Structure, yield and melting point of ligand

Entry Structure




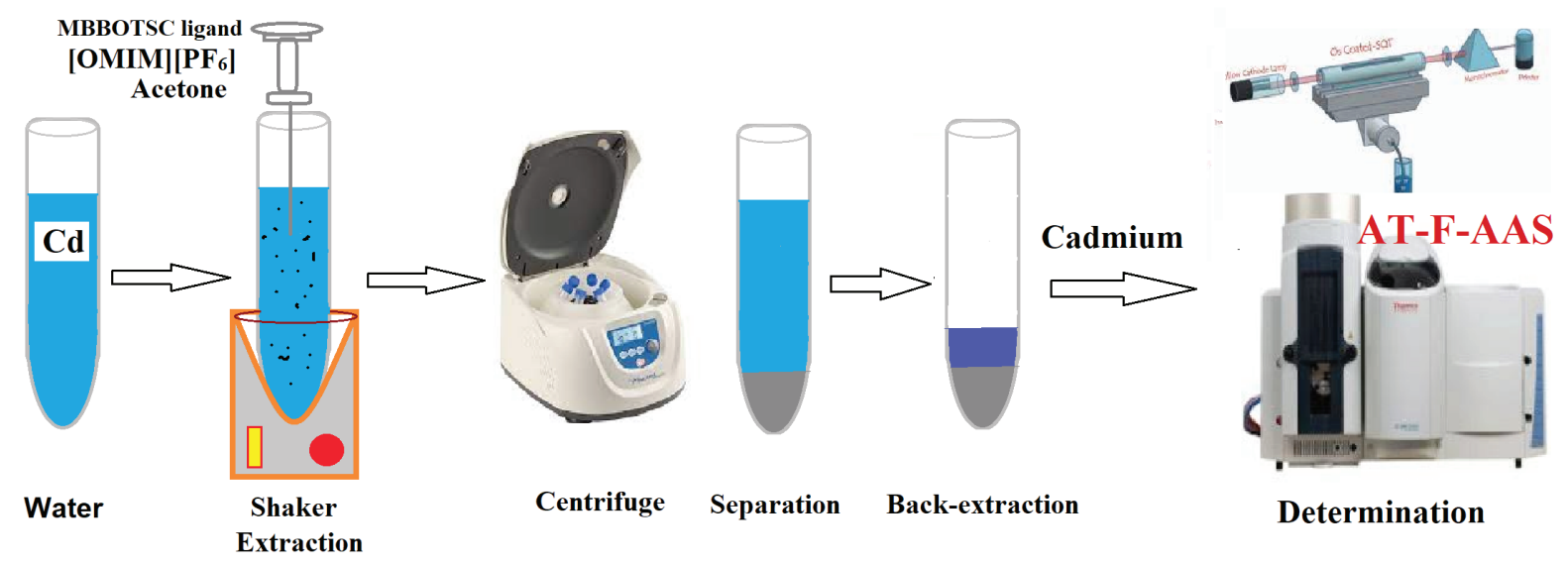

Fig.2. Determination of cadmium based on MBBOTSC ligand by the USA-D-ILLME procedure

\section{Results and Discussion}

The aim of the present study was to synthesize the meta-(4-bromobenzyloxy) benzaldehyde thiosemicarbazone derivative and to confirm its structure by spectroscopic methods such as FTIR, ${ }^{1} \mathrm{H}-\mathrm{NMR}$, and ${ }^{13} \mathrm{C}-\mathrm{NMR}$ and use it to separate and extract the cadmium ions from the water and wastewater samples before determined by AT-FAAS. The meta- (4-bromo benzyloxy) benzaldehyde reacted with thiosemicarbazide under basic condition to form the target ligand. Ligand synthesis is based on a nucleophilic attack of the electron pair of the free amine of thiosemicarbazide on the carbon of the carbonyl of aldehyde group, and after removing of a water molecule from intermediate, an imine bond is formed and the product is obtained.

\subsection{FTIR Analysis}

The FT-IR, ${ }^{1} \mathrm{H}-\mathrm{NMR},{ }^{13} \mathrm{C}-\mathrm{NMR}$ spectra of the synthesized ligand analyzed to confirm its structure. In the FT-IR spectrum of the ligand, two stretching vibration frequencies in the regions of 3393 and $3342 \mathrm{~cm}^{-1}$ belong to the $\mathrm{NH}_{2}$ group. The peak that appearing at the stretching vibration frequency of $3025 \mathrm{~cm}^{-1}$ is related to the aromatic $\mathrm{CH}$ stretching vibrations of this synthesized ligand. The peak that has appeared at $1530 \mathrm{~cm}-1$ is related to the stretching vibration frequency of the $\mathrm{C}=\mathrm{N}$. And the peak appearing at the frequency $1262 \mathrm{~cm}^{-1}$ is correspond to the stretching vibration frequency of the $\mathrm{C}=\mathrm{S}$ functional group. The peak at $834 \mathrm{~cm}^{-1}$ is attributed to the $\mathrm{C}-\mathrm{Br}$ stretching vibration (Fig.3).

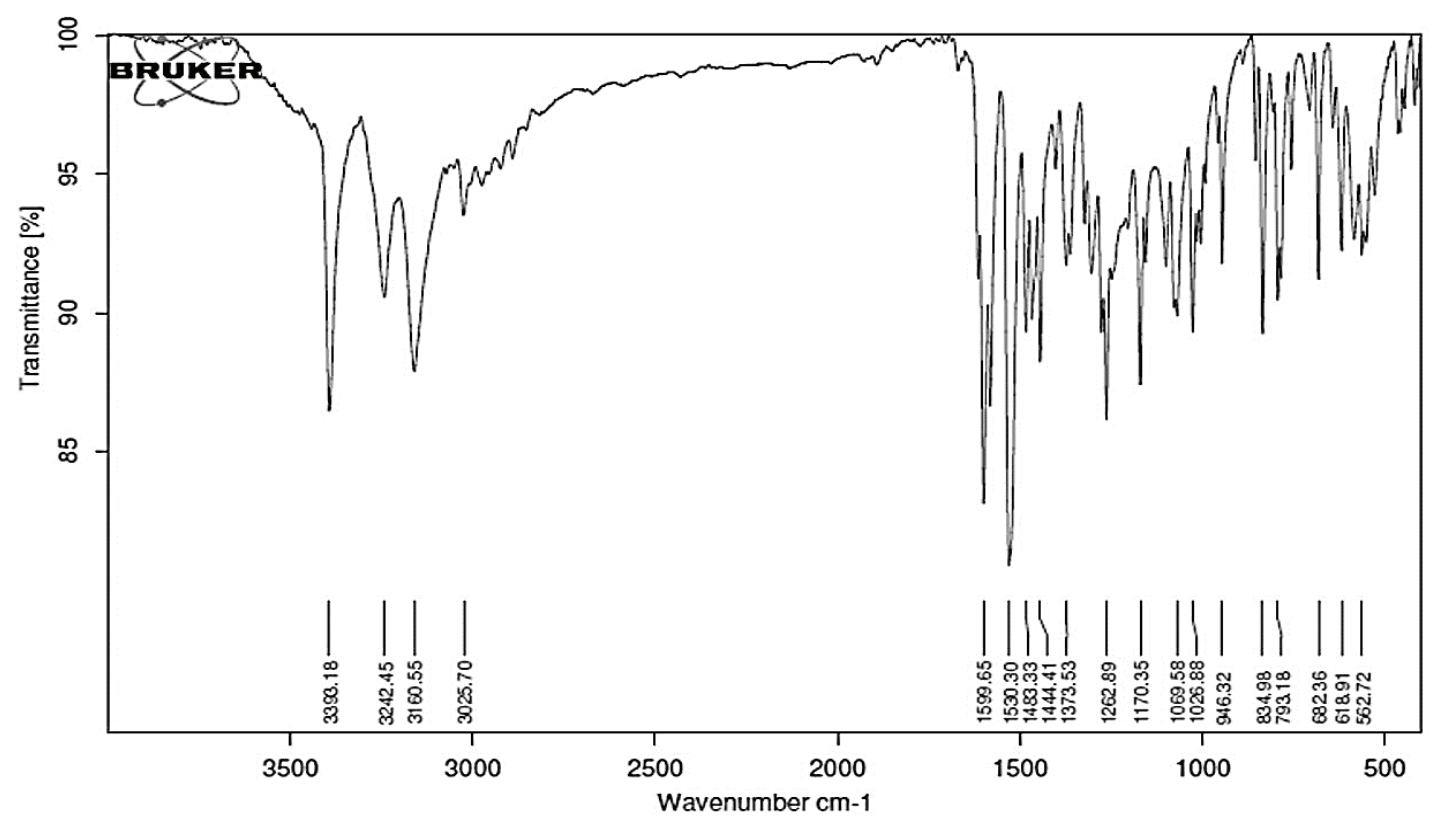

Fig. 3. FT-IR spectrum of MBBOTSC ligand 


\section{2. ${ }^{1}$ H-NMR spectrum}

In the ${ }^{1} \mathrm{H}-\mathrm{NMR}$ spectrum of the ligand, a single peak appeared in the region of $11.48 \mu \mathrm{g} \mathrm{mL}^{-1}$, which corresponds to hydrogen of $\mathrm{NH}$. Two single peaks in the regions of $8.27 \mu \mathrm{g} \mathrm{mL}^{-1}$ and $8.1 \mu \mathrm{g} \mathrm{mL}^{-1}$ belong to the two protons $\mathrm{NH}_{2}$, and the single peak appear at the $8.04 \mu \mathrm{g} \mathrm{mL}^{-1}$ indicate the $\mathrm{CH}$ alkene group. The three aromatic protons appeared as a doublet at the $7.5 \mu \mathrm{g} \mathrm{mL}^{-1}$ with coupling constant $(J) 6 \mathrm{~Hz}$. In the area of $7.45 \mu \mathrm{g} \mathrm{mL}^{-1}$, a doublet with coupling constant $(J) 6 \mathrm{~Hz}$ appeared, which corresponds to two aromatic protons, as well as in the area of 7.35 $\mu \mathrm{g} \mathrm{mL} \mathrm{m}^{-1}$, doublet with coupling constant $(J) 6 \mathrm{~Hz}$ has appeared related to two aromatic protons. In the region $7.03 \mu \mathrm{g} \mathrm{mL}^{-1}$, a triplet peak has appeared with coupling constant $(\mathrm{J}) 6 \mathrm{~Hz}$, which is corresponded to an aromatic proton. The single peak that appears in the region of $5.15 \mu \mathrm{g} \mathrm{mL}-1$ belongs to the two protons of the $\mathrm{OCH}_{2}$ group. The ${ }^{13} \mathrm{C}-\mathrm{NMR}$ spectrum of this compound also confirms the desired structure in that the ligand contains 11 types of carbon, which can be seen in the ${ }^{13} \mathrm{C}$-NMR spectrum as 11 separate carbon peaks (Fig.4 and 5).

\section{Representative spectral data}

Meta-(4-bromobenzyloxy) benzaldehyde thiosemicarbazone $(\mathrm{X})$ : Cream-shaped crystals, m.p.: 187-189 C; FT-IR (KBr) $\left(v_{\max } \mathrm{cm}^{-1}\right): 3393(\mathrm{~N}-\mathrm{H}), 3342(\mathrm{~N}-$ $H), 3160(\mathrm{~N}-\mathrm{H}), 3025\left(\mathrm{C}-\mathrm{H}_{A}\right), 1530(\mathrm{C}=\mathrm{N}), 1262(\mathrm{C}=\mathrm{S})$, $1170(\mathrm{C}-\mathrm{O})$, and $834(\mathrm{C}-\mathrm{Br}) .{ }^{1} \mathrm{H} N \mathrm{NMR}\left(\mathrm{DMSO}-\mathrm{d}_{6} 300 \mathrm{MHz}\right)$ $\delta$ (ppm): 11.48 (1H, s,NH), 8.27 (1H, s, NH), $8.1(1 \mathrm{H}, \mathrm{s}, \mathrm{NH})$, $8.04(1 \mathrm{H}, s, \mathrm{CH}), 7.5\left(3 \mathrm{H}, d, J=6 \mathrm{~Hz}, \mathrm{CH}_{A}\right), 7.45(2 \mathrm{H}, d, J$ $\left.=6 \mathrm{~Hz}, \mathrm{CH}_{A}\right), 7.35\left(2 \mathrm{H}, d, J=6 \mathrm{~Hz}, \mathrm{CH}_{A}\right), 7.03(1 \mathrm{H}, t, J=$ $\left.6 \mathrm{~Hz} \mathrm{CH}_{A}\right)$, and $5.15\left(2 \mathrm{H}, \mathrm{s}, \mathrm{OCH}_{2}\right) \cdot{ }^{13} \mathrm{CNMR}\left(\mathrm{DMSO}-\mathrm{d}_{\sigma} 75\right.$ MHz) $\delta$ (ppm): 178, 158, 142, 136, 136, 131, 130, 121, 117, 112 , and 69 .

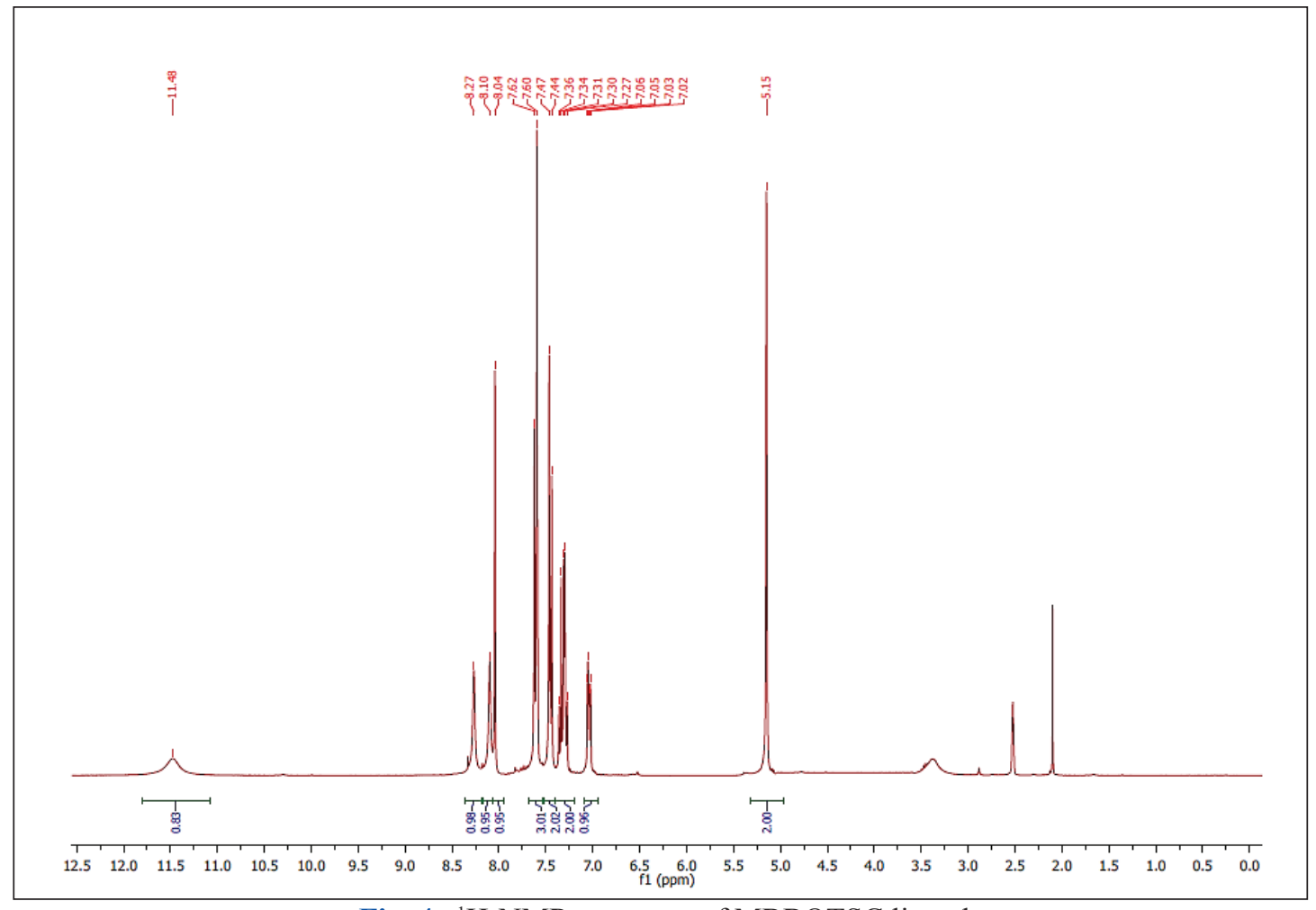

Fig. 4. ${ }^{1} \mathrm{H}-\mathrm{NMR}$ spectrum of MBBOTSC ligand 


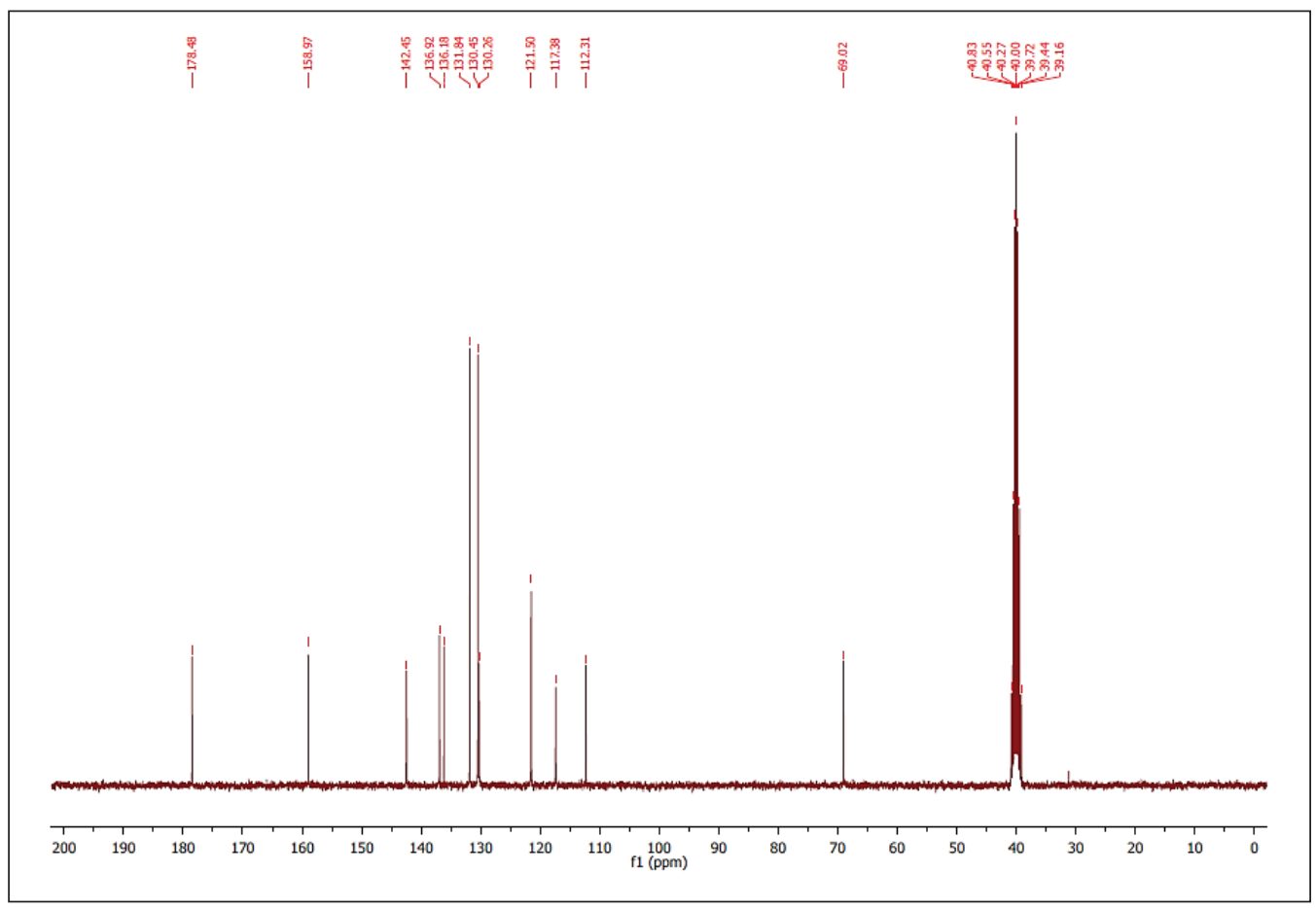

Fig. 5. ${ }^{13} \mathrm{C}-\mathrm{NMR}$ spectrum of MBBOTSC ligand

\subsection{Mechanism of cobalt extraction}

The mechanism of extraction is based on the interaction of imine nitrogen $(=\mathrm{N})$ and thio $(=\mathrm{S})$ groups of the MBBOTSC with cadmium ions using dative/covalent bonding to form stable five ring. The mechanism of extraction between nitrogen and thiol of the MBBOTSC with $\mathrm{Cd}$ ions was shown in Figure 6. The mechanism demonstrates that MBBOTSC ligand can bind to $\mathrm{Cd}^{2+}$ by complex formations that are easily eliminated from the water samples. The sulfur and nitrogen groups in MBBOTSC ligands caused to easily extracted the $\mathrm{Cd}$ ions from aqueous solutions

\subsection{Optimizing of parameters}

\subsubsection{The effect of $\mathrm{pH}$}

The $\mathrm{pH}$ of the sample is the main parameter for cadmium extraction from water and wastewater samples which was affected oncomplexation. So, the effect of $\mathrm{pH}$ on extraction efficiency of cadmium with MBBOTSC ligand was studied in different $\mathrm{pH}$ between 2 to 11 (Fig.7). The complexation of sulfur and nitrogen groups with $\mathrm{Cd}^{2+}$ was depended on the $\mathrm{pH}$ of samples. Due to results, the efficient extraction for $\mathrm{Cd}$ ions was obtained more than $96 \%$ at $\mathrm{pH}$ of $6.0-7.0(\mathrm{Cd} \rightarrow: \mathrm{S}-\mathrm{R}$ or : $\mathrm{NH}_{2}-\mathrm{R}$ ). At higher $\mathrm{pH}$ (more than 7.5), the extraction of cadmium was reduced and $\mathrm{Cd}$ ions was precipited $\left[\mathrm{Cd}(\mathrm{OH})_{2}\right]$. The mechanism was depended on the coordination bond between $\mathrm{Cd}^{2+}$ and amine/sulfur groups of MBBOTSC ligand at optimized $\mathrm{pH}$. In acidic $\mathrm{pH}$, the $\mathrm{NH}_{2}$ and $\mathrm{SH}$ groups of the MBBOTSC ligand are protonated $(+)$ and complexation decreased. Also, in basic $\mathrm{pH}$ at more than 7.5, the $\mathrm{NH}_{2}$ and $\mathrm{SH}$ groups were deprotonated (-) but the cadmium ions precipitated. So, the MBBOTSC is favorite ligand for extraction and determination of cadmium in water samples by the USA-D-ILLME procedure at $\mathrm{pH} 6.5$. 


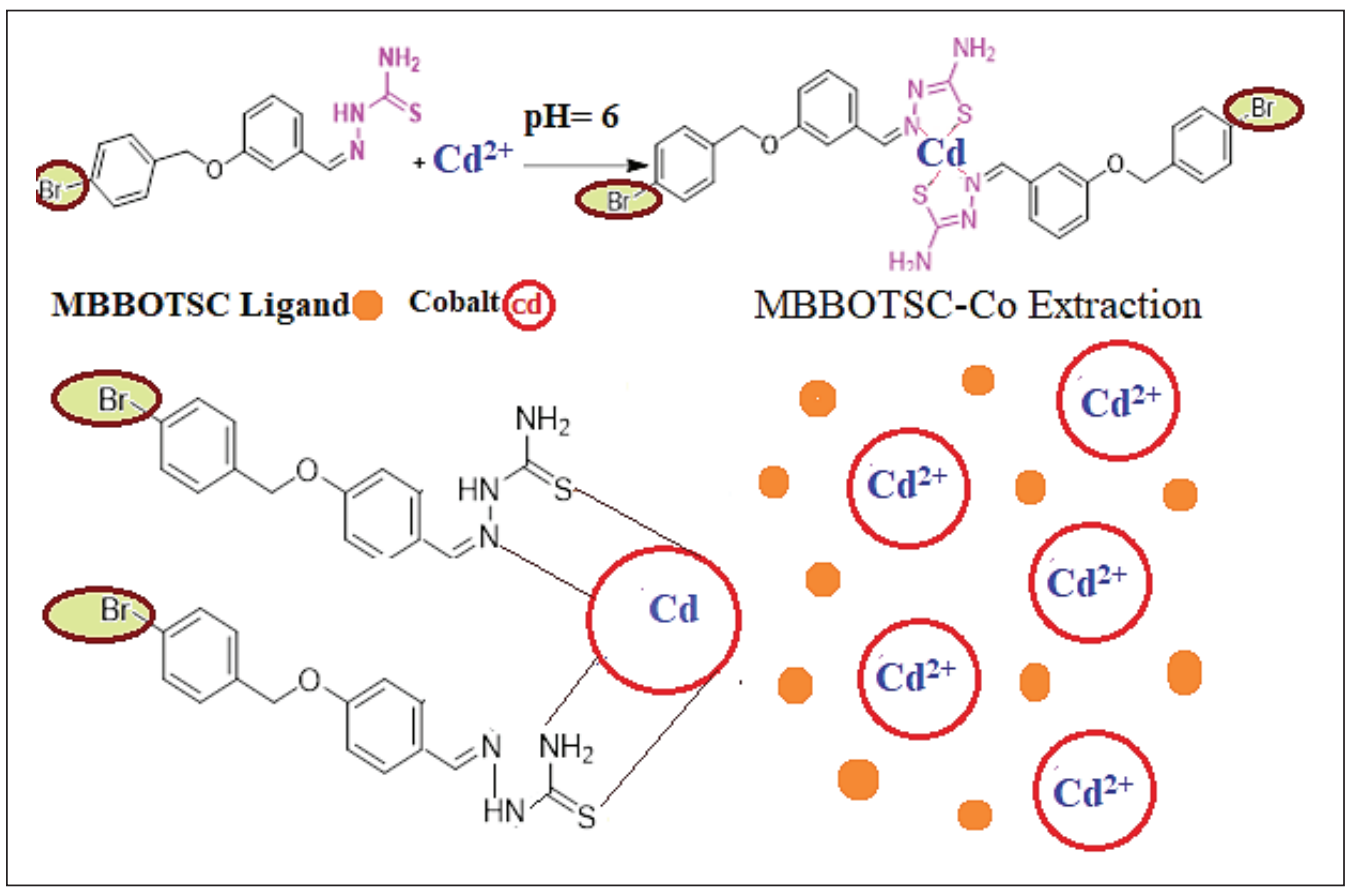

Fig.6.The mechanism of extraction between nitrogen and thiol of the MBBOTSC ligand with cobalt ions

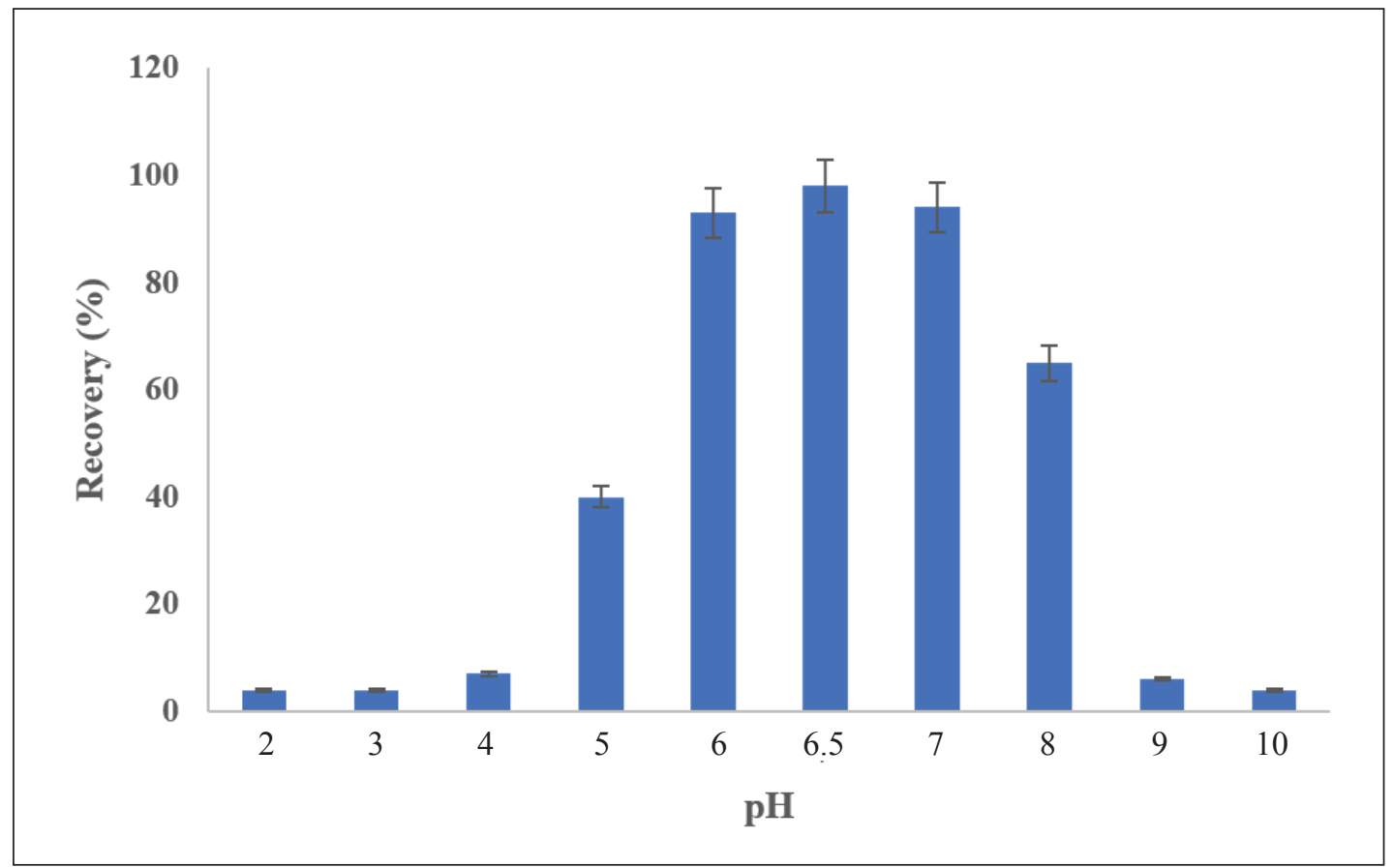

Fig. 7. The effect of $\mathrm{pH}$ on cadmium extraction based on MBBOTSC ligand by the USA-D-ILLME procedure 


\subsubsection{The effect of IL}

The different hydrophobic ionic liquid such as, [OMIM] $\left[\mathrm{PF}_{6}\right],[\mathrm{BMIM}]\left[\mathrm{PF}_{6}\right]$ and $[\mathrm{EMIM}]\left[\mathrm{PF}_{6}\right]$ was used for collecting and separation ligand/Cd from water samples (Fig. 8). So, the effect of ILs on the cadmium extraction was evaluated within the IL range (0.1-0.5 g) by standard cadmium solution (1-36 $\left.\mu \mathrm{g} \mathrm{L}^{-1}\right)$. Due to results, the high recoveries were achieved by $0.17 \mathrm{~g}$ of [OMIM] [PF $\left.{ }_{6}\right](98.9 \%)$. Therefore, $0.2 \mathrm{~g}$ of [OMIM] $\left[\mathrm{PF}_{6}\right]$ was used as optimum IL for $\mathrm{Cd}$ extraction by MBBOTSC ligand.

\subsubsection{Optimization of MBBOTSC ligand}

The effect of MBBOTSC for cadmium extraction mustbeevaluated.MBBOTSC is one of the important factor for cadmium extraction which should be optimized by the USA-D-ILLME procedure. First, $0.015 \times 10^{-4}-0.35 \times 10^{-4} \mathrm{~mol} \mathrm{~L}^{-6}$ of MBBOTSC ligand was examined for cadmium extraction in the water and standard samples. Due to results, the recovery of extraction increased for $0.065 \times 10^{-4}$ - $0.35 \times 10^{-4} \mathrm{~mol} \mathrm{~L}^{-6}$ of MBBOTSC ligand (Fig. 9). So, $0.07 \times 10^{-4} \mathrm{~mol} \mathrm{~L}^{-1}$ of MBBOTSC ligand in $50 \mathrm{~mL}$ of water sample was selected as optimum amount of ligand for cadmium extraction.

\subsubsection{Effect of back-extraction eluents}

The effect of back-extraction eluents for cadmium extraction in water samples were studied by MBBOTSC ligand. At acidic $\mathrm{pH}(\mathrm{pH}<4)$, the covalent bond between the cadmium ions and sulfur/nitrogen groups (complexation) was broken and cadmium ions released into eluents. For this purpose, the different acid solutions $\left(\mathrm{HCl}, \mathrm{HNO}_{3}\right.$, $\mathrm{H}_{2} \mathrm{CO}_{3}, \mathrm{H}_{2} \mathrm{SO}_{4}$ ) were prepared and used for backextraction cadmium ions fron ligand/IL in water and wastewater samples. In-addition, the eluent concentrations and volumes between 0.1-1.0 mol L ${ }^{-1}$ and 0.1-2.0 $\mathrm{mL}$ ) was studied. The results showed, the high extraction for cadmium was achieved by $0.5 \mathrm{~mL}$ of nitric acid ( $0.5 \mathrm{M})$ (Fig. 10).

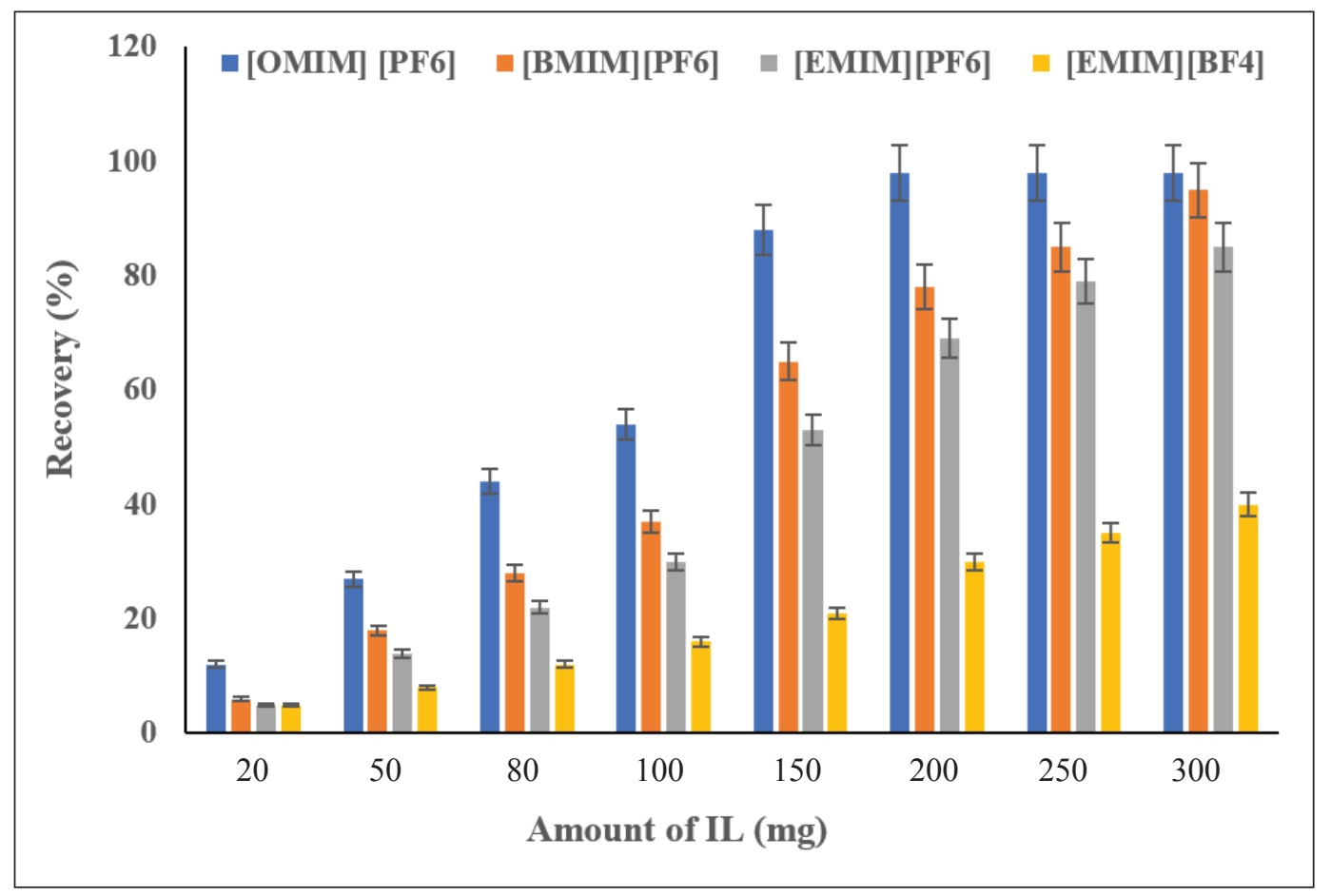

Fig. 8. The effect of amount of IL on cadmium extraction based on MBBOTSC ligand by the USA-D-ILLME procedure 


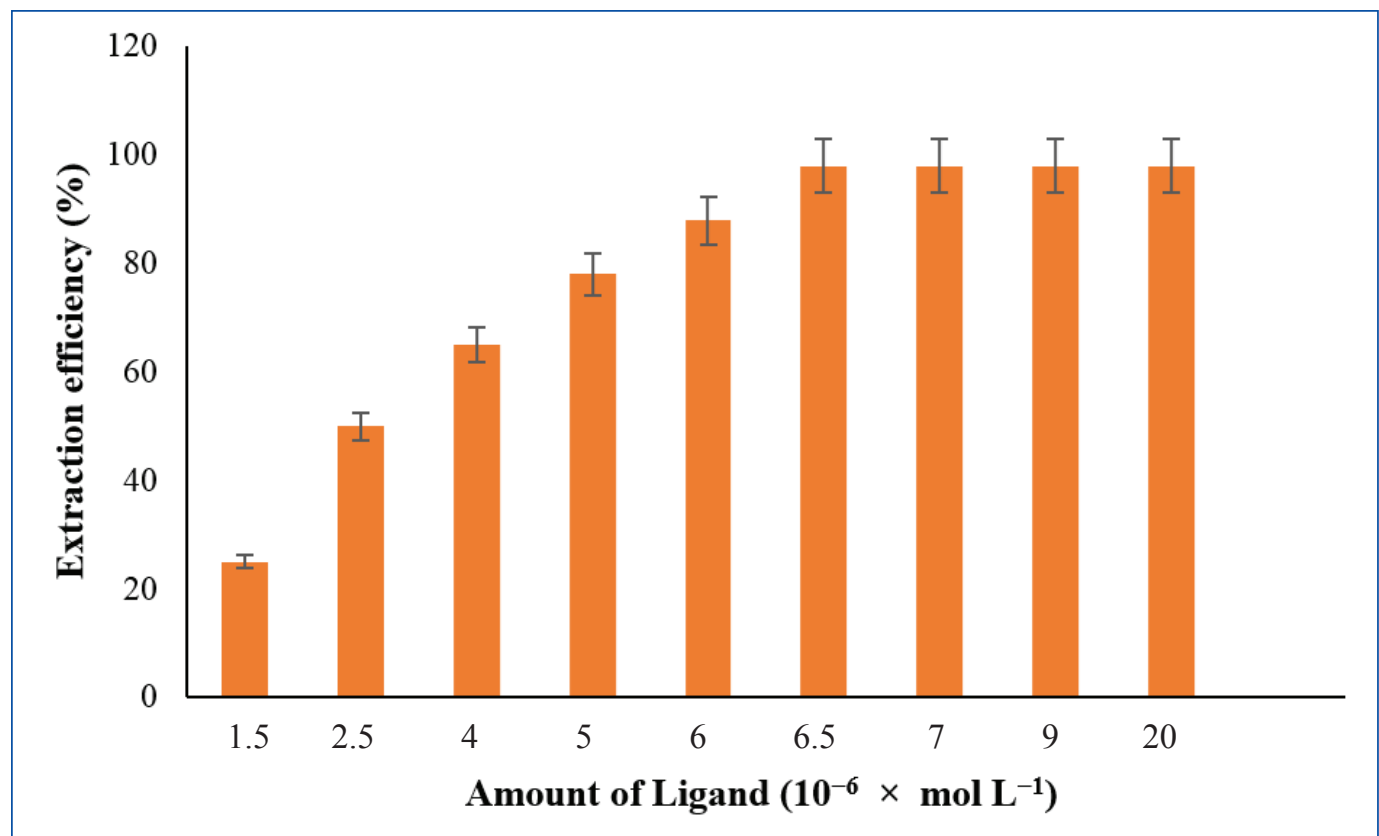

Fig. 9. The effect of ligand on cadmium extraction by the USA-D-ILLME procedure

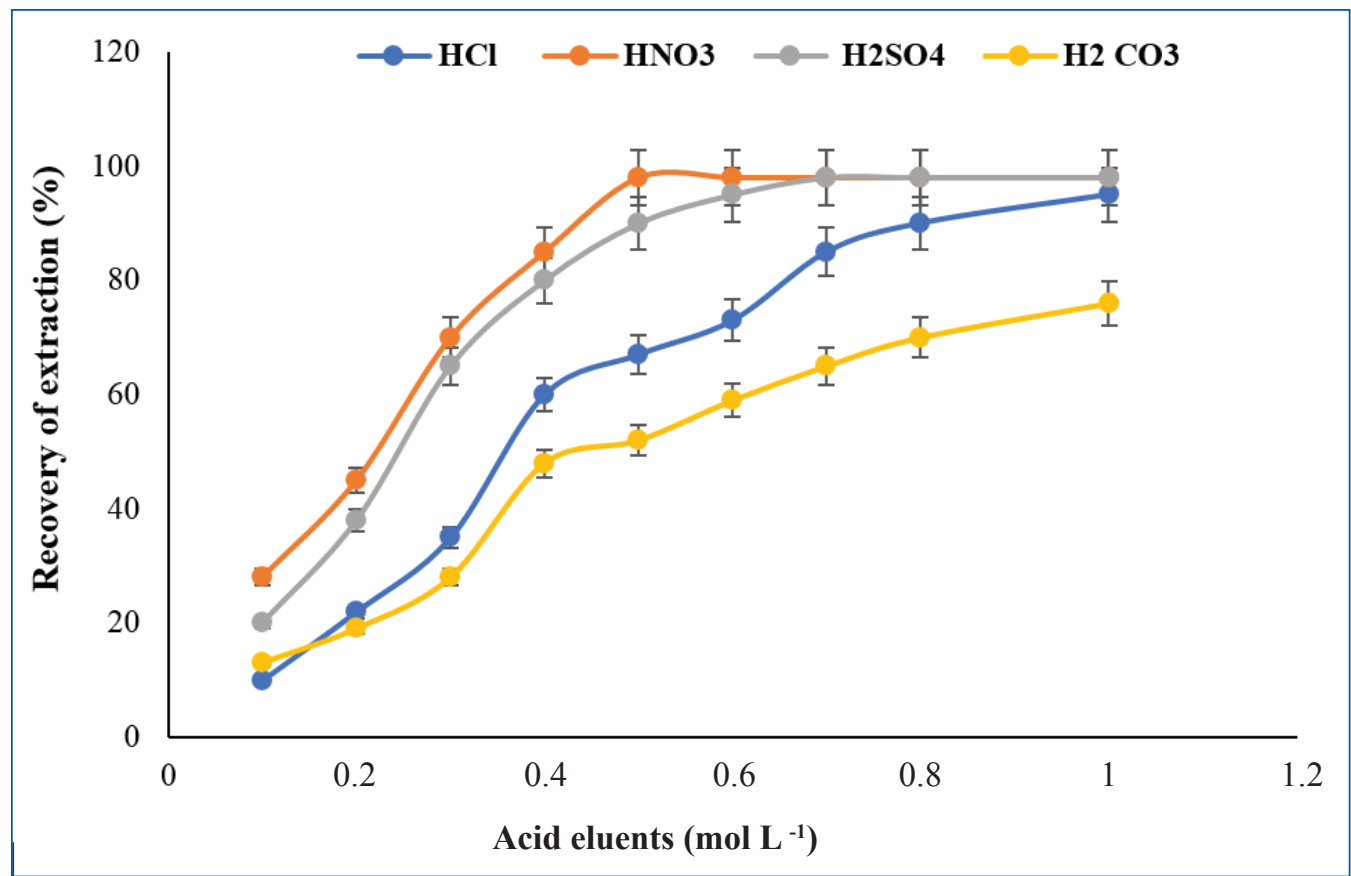

Fig. 10. The effect of eluents on cadmium extraction based on MBBOTSC ligand by the USA-D-ILLME procedure 


\subsubsection{Effect of sample volume}

The effect of sample volume for cadmium extraction in water samples was evaluated between $5-100$ $\mathrm{mL}$ with cadmium concentration (1-36 $\left.\mu \mathrm{g} \mathrm{L}^{-1}\right)$ by AT-F-AAS. As result, the high recovery occurred less than $60 \mathrm{~mL}$ of water samples at $\mathrm{pH}$ 6.5. So, $50 \mathrm{~mL}$ was selected as optimum sample volume for cadmium extraction based on the MBBOTSC ligand by the USA-D-ILLME procedure.

\subsection{Validation of methodology}

The cadmium ions $\left(\mathrm{Cd}^{2+}\right)$ was separated and determined in water and standard samples by the USA-D-ILLME procedure. The cadmium ions were successfully extracted based on MBBOTSC ligand in water samples with high recovery. Moreover, the accuracy of cadmium analysis must be validated by advanced analytical techniques and spiking samples. In this study, the results of USA-D-ILLME procedure was validated by spiking the standard cadmium solution in water samples (Table 2). Also, the data analysis of cadmium in this procedure can be validated by ET-AAS (Table 3). The results demonstrated the accurate extraction and high recovery for cadmium ions in water and wastewater samples. The spiked samples showed satisfactory results for extraction and separation of cadmium based on the MBBOTSC ligand in water samples by the USA-D-ILLME procedure.

\section{Conclusions}

An analytical method for extraction and determination of cadmium in water samples was carried out by synthesis of meta-(4-bromobenzyloxy) benzaldehyde thiosemicarbazone (MBBOTSC) as a novel ligand at $\mathrm{pH}$ 6.5. The complexation between cadmium and ligand was achieved with the MBBOTSC ligand and cadmium extracted by the USA-D-ILLME procedure. By the proposed procedure, the simple and fast extraction, as well as the efficient separation for cadmium ions was obtained at optimized conditions. Results showed the LOD, the working range and RSD ranges were obtained at $0.3 \mu \mathrm{g} \mathrm{L}^{-1}, 1-75 \mu \mathrm{g} \mathrm{L}^{-1}$ and $1.12 \%$ $2.54 \%$, respectively. Due to results, the separation cadmium in water samples was simply achieved by the IL phase before determined by AT-F-AAS.

Table 2. The validation of results for cadmium extraction based on the MBBOTSC ligand in water samples by spiking standard solution $\left(\mu \mathrm{g} \mathrm{L}^{-1}\right)$.

\begin{tabular}{lccc}
\hline Samples & Added & USA-D-ILLME $*$ & Recovery (\%) \\
\hline Drinking Water & ---- & $0.45 \pm 0.02$ & ---- \\
& 0.5 & $0.94 \pm 0.05$ & 102 \\
Well water & 1.0 & $1.47 \pm 0.07$ & $---{ }^{--}$ \\
& ---- & $5.14 \pm 0.19$ & 96.2 \\
Wastewater & 5.0 & $9.95 \pm 0.44$ & 101.1 \\
& 10 & $15.25 \pm 0.62$ & 98.2 \\
Wastewater & ---- & $9.85 \pm 0.46$ & 99.3 \\
& 5 & $14.76 \pm 0.67$ & 104.3 \\
\hline
\end{tabular}

* Mean of three determinations \pm cconfidence interval $(\mathrm{P}=0.95, \mathrm{n}=5)$

Wastewater prepared from petrochemical industry in Arak and well water from south ofTehran (Share-Ray) 
Table 3. The validation of methogology for cadmium extraction and determination in water by spiking samples and comparing to the ET-AAS analyzer

\begin{tabular}{|c|c|c|c|c|c|}
\hline Samples & $\begin{array}{l}\text { Added } \\
\left(\mu g \mathrm{~L}^{-1}\right)\end{array}$ & $\begin{array}{l}\text { ET-AAS } * \\
\left(\mu g \mathrm{~L}^{-1}\right)\end{array}$ & $\begin{array}{c}\text { USA-D-ILLME } * \\
\left(\mu \mathrm{g} \mathrm{L}^{-1}\right)\end{array}$ & $\begin{array}{c}\text { Recovery (\%) } \\
\text { ET-AAS }\end{array}$ & $\begin{array}{c}\text { Recovery (\%) } \\
\text { USA-D-ILLME }\end{array}$ \\
\hline \multirow[t]{2}{*}{ Drinking Water } & ----- & $0.73 \pm 0.03$ & $0.69 \pm 0.02$ & ----- & ----- \\
\hline & 0.5 & $1.21 \pm 0.05$ & $1.22 \pm 0.06$ & 96.0 & 106 \\
\hline \multirow[t]{2}{*}{ Well water } & ----- & $3.76 \pm 0.16$ & $3.82 \pm 0.18$ & ----- & ----- \\
\hline & 3.0 & $6.72 \pm 0.29$ & $6.77 \pm 0.32$ & 98.6 & 98.3 \\
\hline \multirow[t]{2}{*}{ Wastewater } & ----- & $14.02 \pm 0.71$ & $13.87 \pm 0.64$ & & \\
\hline & 15 & $28.56 \pm 1.28$ & $29.03 \pm 1.42$ & 96.9 & 101.1 \\
\hline \multirow[t]{2}{*}{ Wastewater } & ----- & $16.32 \pm 0.78$ & $16.15 \pm 0.81$ & & \\
\hline & 20 & $36.25 \pm 1.68$ & $35.58 \pm 1.74$ & 99.7 & 97.2 \\
\hline
\end{tabular}

* Mean of three determinations \pm cconfidence interval $(\mathrm{P}=0.95, \mathrm{n}=5)$

Wastewater prepared from petrochemical industry in Arak and well water from south ofTehran (Share-Ray)

\section{Acknowledgments}

We thank the Department of Medicinal Chemistry, Faculty of Pharmacy, Kerman University of Medical Sciences, Kerman, and Environmental Engineering, Faculty of Natural Resources, Islamic Azad University, Bandar Abbas Branch for support of this work.

\section{References}

[1] L.N. Suvarapu, A.R. Somala, J.R. Koduru, S.O.k. Baek, V.R. Ammireddy, A critical review on analytical and biological applications of thio- and phenylthiosemicarbazones, Asian. J. Chem, 24 (2012) 1889-1898. https://asianjournalofchemistry.co.in/Home.aspx

[2] S.A. Hosseini-Yazdi, S. Hosseinpour, A.A. Khandar, W.S. Kassel, N.A. Piro, Copper (II) and nickel (II) complexes with two new bis(thiosemicarbazone) ligands: Synthesis, characterization, X-ray crystal structures and their electrochemistry behavior, Inorganica. Chim. Acta, 427 (2015) 124-130. https://doi. org/10.1016/j.ica.2014.12.011.

[3] İ. Kizilcikli, Y.D. Kurt, B. Akkurt, A.Y. Genel, S. Birteksöz, G. Ötük, B. Ülküseven, Antimicrobial activity of a series of thiosemicarbazones and their ZnII and PdII complexes, Folia. Microbiol., 52 (2007) 15-25. https://doi. org/10.1007/BF02932132.
[4] C. Shipman, Jr., S.H. Smith, J.C. Drach, D.L. Klayman, Antiviral activity of 2-acetylpyridine thiosemicarbazones against herpes simplex virus, Antimicrob. Agents. Chemother, 19 (1981) 682-685. https://dx.doi.org/10.1128\%2Faac.19.4.682.

[5] M.C. Soraires Santacruz, M. Fabiani, E.F. Castro, L.V. Cavallaro, L.M. Finkielsztein, Synthesis, antiviral evaluation and molecular docking studies of N4-aryl substituted/unsubstituted thiosemicarbazones derived from 1-indanones as potent anti-bovine viral diarrhea virus agents, Bioorg. Med. Chem, (2017) 4055-4063. https:// doi.org/10.1016/j.bmc.2017.05.056.

[6] J. Qi, X. Wang, T. Liu, M. Kandawa-Schulz, Y. Wang, X. Zheng, Synthesis, antiproliferative activity and mechanism of copper(II)-thiosemicarbazone complexes as potential anticancer and antimicrobial agents, J. Coord. Chem., 73 (2020) 1208-1221. https://doi.org/10.1080/009 58972.2020 .1768378 .

[7] D. Rogolino, A. Gatti, M. Carcelli, G. Pelosi, F. Bisceglie, F.M. Restivo, F. Degola, A. Buschini, S. Montalbano, D. Feretti, C. Zani, Thiosemicarbazone scaffold for the design of antifungal and antiaflatoxigenic agents: evaluation of ligands and related copper complexes, Sci. Rep, 7 (2017) 11214. https://doi.org/10.1038/ 
s41598-017-11716-w.

[8 M. Whitnall, J. Howard, P. Ponka, D.R. Richardson, A class of iron chelators with a wide spectrum of potent antitumor activity that overcomes resistance to chemotherapeutics, Proc. Nat. Acad. Sci., 103 (2006) 14901. https://doi. org/10.1073/pnas.0604979103.

[9] R.H. Vekariya, K.D. Patel, D.P. Rajani, S.D. Rajani, H.D. Patel, A one pot, three component synthesis of coumarin hybrid thiosemicarbazone derivatives and their antimicrobial evolution, J. Assoc. Arab Univ. Basic Appl. Sci, 23 (2017) 10-19. https://doi.org/10.1016/j.jaubas.2016.04.002.

[10] S. Cunha, T.L.d. Silva, One-pot and catalyst-free synthesis of thiosemicarbazones via multicomponent coupling reactions, Tetrahedron. Lett, 50 (2009) 2090-2093. https://doi. org/10.1016/j.tetlet.2009.02.134.

[11] M. Tyagi, S. Chandra, Synthesis, characterization and biocidal properties of platinum metal complexes derived from 2,6-diacetylpyridine (bis thiosemicarbazone), Open J. Inorg. Chem, 02 (2012). http://dx.doi.org/10.4236/ ojic.2012.23007.

[12] A. Asadipour, Y. Pourshojaei, K. Eskandari, A. Foroumadi, A short synthesis of 7-amino alkoxy homoisoflavonoides, RSC Adv, 7 (2017) 44680-44687. https://doi.org/10.1039/ C7RA08990B.

[13] Y. Pourshojaei, F. Zolala, K. Eskandari, M. Talebi, L. Morsali, M. Amiri, A. Khodadadi, R. Shamsimeymandi, E. Faghih-Mirzaei, A. Asadipour, Nickel ferrite $\left(\mathrm{NiFe}_{2} \mathrm{O}_{4}\right)$ nanoparticles as magnetically recyclable nanocatalyst for highly efficient synthesis of 4H-chromene derivatives, J. nanosci. nanotechnol, 20 (2020) 3206-3216. https://doi.org/10.1166/jnn.2020.17396.

[14] Y. Pourshojaei, A. Abiri, R. Eskandari, F. Dourandish, K. Eskandari, A. Asadipour, Synthesis, biological evaluation, and computational studies of novel fused six-membered O-containing heterocycles as potential acetylcholinesterase inhibitors, Comput. Biol. Chem, 80 (2019) 249-258. https://doi.org/10.1016/j.compbiol- chem.2019.04.004.

[15] Y. Pourshojaei, M. Nikzad, K. Eskandari, M. Darijani, A. Hassanzadeh, E. Faghih-Mirzaei, A.J.C.C.A. Asadipour, Ultrasound-assisted and efficient knoevenagel condensation reaction catalyzed by silica sodium carbonate nanoparticles, Croat. Chem. Acta, 91 (2018) 19-28. https://doi.org/10.5562/CCA3261.

[16] Y. Pourshojaei, A. Nasiri, Cobalt separation from water and food samples based on penicillamine ionic liquid and dispersive liquid-liquid microextraction before determination by AT-FAAS, Anal. Method. Environ. Chem. J, 4 (2021) 21-32. https://doi.org/10.24200/amecj. v4.i03.148.

[17] B.Z. Sibuh, S. Khanna, P. Taneja, P. Sarkar, N.K. Taneja, Molecular docking, synthesis and anticancer activity of thiosemicarbazone derivatives against MCF-7 human breast cancer cell line, Life. Sci, 273 (2021) 119305. https://doi. org/10.1016/j.1fs.2021.119305.

[18] I.D. Kostas, B.R. Steele, Thiosemicarbazone complexes of transition metals as catalysts for cross-coupling reactions, catal., 10 (2020) 1107. https://doi.org/10.3390/catal10101107.

[19] M.K. Bharty, A. Bharti, R. Chaurasia, U.K. Chaudhari, S.K. Kushawaha, P.K. Sonkar, V. Ganesan, R.J. Butcher, Synthesis and characterization of $\mathrm{Mn}(\mathrm{II})$ complexes of 4-phenyl(phenyl-acetyl)-3-thiosemicarbazide, 4-amino-5-phenyl-1,2,4-triazole-3-thiolate, and their application towards electrochemical oxygen reduction reaction, Polyhedron, 173 (2019) 114125. https://doi.org/10.1016/j. poly.2019.114125.

[20] Q. Yuan, R. Cheng, S. Zou, C. Ding, H. Liu, Y. Wang, D. Yang, X. Xiao, Q. Jiang, R. Tang, J. Chen, Isatin thiosemicarbazone derivatives as inhibitors against corrosion of AA6060 aluminium alloy in acidic chloride medium: substituent effects, J. Mater. Res. Technol, 9 (2020) 11935-11947. https://doi.org/10.1016/j. jmrt.2020.08.012.

[21] S. Bhattacharya, The role of probiotics in the amelioration of cadmium toxicity, Biol. Trace. 
Elem. Res, 197 (2020) 440-444. https://doi. org/10.1007/s12011-020-02025-x.

[22] M. Wang, Z. Chen, W. Song, D. Hong, L. Huang, Y. Li, A review on cadmium exposure in the population and intervention strategies against cadmium toxicity, Bull. Environ. Contam. Toxicol, 106 (2021) 65-74. https://doi. org/10.1007/s00128-020-03088-1.

[23] Y. Huang, C. He, C. Shen, J. Guo, S. Mubeen, J. Yuan, Z. Yang, Toxicity of cadmium and its health risks from leafy vegetable consumption, Food. Funct, 8 (2017) 1373-1401. https://doi. org/10.1039/C6FO01580H.

[24] ATSDR, Agency for Toxic Substances and Disease Registry, 2016. 4770 Buford Hwy NE, Atlanta, GA 30341 Contact CDC: 800-232-4636 / TTY: 888-232-6348. https://www.atsdr.cdc. gov/dro/central_branch.html

[25] ACGIH, Documentation of the Threshold Limit Values(TLVs) and Biological Exposure Indices, American Conference of Governmental Industrial Hygienists, 2016 7th Ed. https://www. acgih.org/science/tlv-bei-guidelines/

[26] M. Banihashemi, N. Dalali, N. Sehati, B. Farajmand, Decoration of Fe3O4@SiO2@ZnO as a high performance nanosorbent on a stir bar microextraction device for preconcentration and determination of cadmium in real water samples, Microchem. J, 154 (2020) 104599. https:// doi.org/10.1016/j.microc.2020.104599.

[27] Y. Ji, M. Zhao, A. Li, L. Zhao, Hydrophobic deep eutectic solvent-based ultrasonic-assisted dispersive liquid-liquid microextraction for preconcentration and determination of trace cadmium and arsenic in wine samples, Microchem. J, 164 (2021) 105974. https://doi. org/10.1016/j.microc.2021.105974.

[28] D. Martínez, G. Grindlay, L. Gras, J. Mora, Determination of cadmium and lead in wine samples by means of dispersive liquid-liquid microextraction coupled to electrothermal atomic absorption spectrometry, J. Food. Compost. Anal, 67 (2018) 178-183. https://doi. org/10.1016/j.jfca.2018.01.013.

[29] A. Girgin, N. Atsever, T. Borahan, Z. Tekin, Ç.
Büyükpınar, N. San, S. Bakırdere, Determination of cadmium in mineral water samples by slotted quartz tube-flame atomic absorption spectrometry after peristaltic pump assisted silica nanoparticle based pipette tip solid phase extraction, Water. Air. Soil. Pollut, 232 (2021) 422. https://doi.org/10.1007/s11270-02105386-8.

[30] F. Sabermahani a, R. askari b, S.J. Hosseinifard, M. Saeidi, Determination of cadmium in water and environmental samples by inductively coupled plasma atomic emission spectrometry after solid phase extraction using thiosemicarbazide derivative on alumina, Scientia Iranica, 21 (2014) 2012-2020. http://scientiairanica.sharif. edu/issue_153_304.html

[31] Y. Takaku, K. Ishizuka, A. Nagaoka, M. Minakawa, T. Morita, K. Fujimoto, Determination of cadmium in sea water by ICP-MS with chelating resin preconcentration, Bunseki. kagaku, 65 (2016) 399-402. http://dx.doi.org/10.2116/ bunsekikagaku.65.399.

[32] X. Wang, H. Liu, C. Lin, L. Pang, J. Yang, Q. Zeng, Optimization of ultrasound-assisted magnetic retrieval-linked ionic liquid dispersive liquid-liquid microextraction for the determination of cadmium and lead in water samples by graphite furnace atomic absorption spectrometry, J. Ind. Eng. Chem, 56 (2017) 321-326. http://dx.doi.org/10.1016/j.jiec.2017.07.027.

[33] L. Esfanjani, N. Farhadyar, H.R. Shahbazi, F. Fathi, Development of a method for cadmium ion removal from the water using nano $\gamma$-alumina/ $\beta$-cyclodextrin, Toxicol. Rep., 8 (2021) 1877-1882. https://doi.org/10.1016/j.toxrep.2021.11.009.

[34] J. S. Lan, T. Zhang, Y. Liu, Y. Zhang, J.-w. Hou, S.-S. Xie, J. Yang, Y. Ding, Z. Z. Cai, Synthesis and evaluation of small molecules bearing a benzyloxy substituent as novel and potent monoamine oxidase inhibitors, Med. Chem. Comm., 8 (2017) 471-478. https://doi. org/10.1039/C6MD00586A. 